Indonesian Journal of Biotechnology, December, 2014

Vol. 19, No. 2, pp.153-158

\title{
The assessment of genetic variability and taxonomic affinity of local pummelo accessions from Yogyakarta, Indonesia based on RAPD
}

\author{
Ratna Susandarini ${ }^{1 *}$, Rina Arifati ${ }^{1}$, Abdul Razaq Chasani ${ }^{1}$, and Siti Subandiyah ${ }^{2}$
}

${ }^{1}$ Faculty of Biology, Universitas Gadjah Mada, Indonesia

${ }^{2}$ Faculty of Agriculture, Universitas Gadjah Mada, Indonesia

\begin{abstract}
Pummelo (Citrus maxima) is one of three biotypes considered as true species within the genus Citrus. A major issue of pummelo taxonomy in Indonesia is the high number of cultivars showing variability in phenotypic characters but of unknown genetic diversity. In this study, the assessment of genetic variability and taxonomic affinity of local accessions of C. maxima from Yogyakarta was examined based on RAPD fingerprinting. The availability of universal primers and technical simplicity makes RAPD as a molecular tool of choice for the assessment of genetic variability at various taxonomic levels. In this study, 13 accessions of $C$. maxima collected from Yogyakarta were observed for their genetic variability. An additional three registered cultivars were included for comparative purpose. Two decamer primers used for the amplification of DNA produced 222 bands with 174 of them were polymorphic. The data was subjected to cluster analysis to observe the grouping of accessions and taxonomic affinity. Results indicated high genetic variability among accessions. The dendrogram constructed using UPGMA method based on simple matching coefficient showed two main clusters were which was in line to morphological characters. The grouping of accessions showed clear differentiation between accessions bearing white and those with reddish fruit flesh, and thus demonstrates taxonomic value of this study in recognizing important agronomic character for this tropical fruit crop.
\end{abstract}

Keywords: Citrus maxima, taxonomic affinity, genetic variability, RAPD.

\section{Introduction}

Citrus spp. is a group of tropical fruits with high potential as an important agricultural commodity in many countries. The importance of Citrus spp. could be observed from its management efforts in some Asian countries under the program of Global Environment Facilities (GEF). This program was developed for the documentation and conservation of exotic tropical fruits, including mango (Mangifera indica), citrus (Citrus spp.), mangosteen (Garcinia mangostana), and rambutan (Nephelium lappaceum) (GEF, 2006).

Pummelo (Citrus maxima (Burm.) Merr.) is one species of citrus originated from

\section{*Corresponding author:}

Ratna Susandarini

Faculty of Biology, Universitas Gadjah Mada, Indonesia_ratna-susandarini@ugm.ac.id tropical areas of Asia, and known as having high phenotypic variability (Niyomdham, 1992). Pummelo grows well on various soil types at lowland areas to the altitude of 400 $\mathrm{m}$ above sea level, and could be harvested twice to four times a year. One of the serious problems of pummelo in Indonesia is the decline of its genetic variability. Arora (2000) suggested that there was an indication on the decline of pummelo variability in Indonesia and Malaysia as a result of genetic erosion. A possible cause of this decline is lack of concern in preserving pummelo which is considered as underutilized citrus fruits due to its relatively low economic value compared to sweet orange and mandarins.

A common problem threatening diversity of tropical fruit species and their uncultivated close relatives exist in natural habitat as landraces also caused by habitat destruction as a result of unsustainable 
development (Trinh et al., 2003; GEF, 2006). Inventory study on pummelo genetic variability is thus worth particular attention to prevent this potential fruit crop from vanishing before its biological potential is fully discovered.

DNA fingerprinting was defined as any multilocus approach of visualizing DNA polymorphisms, either generated from hybridization or PCR-based techniques (Weising et al., 1995). Random amplified polymorphic DNA (RAPD) developed by Williams et al. (1990) is a PCR-based fingerprinting technique which uses single primer of arbitrary nucleotide sequence to amplify random DNA segments. The application of RAPD in the assessment of genetic variability studies has been reported at various taxonomic levels, ranging from familial (Prasad, 2014), generic (El-Mouei et al., 2011), to species and cultivar levels (Baig et al., 2009).

Previous research on genetic variability of pummelo in Indonesia is still limited to a small number of cultivars from production center areas such as Magetan, East Java as reported by Karsinah et al. (2002), Purwanto et al. (2005), Rakhman et al. (2005), and Agisismanto \& Supriyanto (2007). These studies were conducted only on widely cultivated pummelos, and to this point there was no record on the studies on pummelo landraces occurred as home yard plants. The objective of this study is, therefore, assessing genetic variability of pummelo accessions occurred as home yard plants from Yogyakarta which is assumed to host some local landraces.

\section{Materials and Methods}

Leaves samples were collected from healthy pummelo trees from Gunungkidul, Yogyakarta. Fresh leaves were washed to remove dirt followed by surface sterilization using 70\% ethanol. DNA extraction from $0.2 \mathrm{~g}$ of fresh leaf sample was done using DNAMITE ${ }^{\circledR}$ Plant Kit Extraction (Microzone, UK) according to manufacturer's protocol.
RAPD reaction was performed in $25 \mu \mathrm{L}$ tube containing $20 \mu \mathrm{L}$ volume of reaction mixture with $0.2 \mu \mathrm{M}$ of primer and $15 \mathrm{ng}$ of genomic DNA. The amplification reaction were carried out using a Biorad ${ }^{\mathrm{TM}}$ thermal cycler with the following cycling program: $5 \mathrm{~min}$ denaturation step at $95^{\circ} \mathrm{C} ; 45$ cycles of $30 \mathrm{~s}$ at $94^{\circ} \mathrm{C}, 45 \mathrm{~s}$ at $36^{\circ} \mathrm{C}, 1 \mathrm{~min}$ at $72^{\circ} \mathrm{C}$; and $5 \mathrm{~min}$ at $72^{\circ} \mathrm{C}$ for the final elongation step. Six RAPD primers were screened for their suitability in amplifying C.maxima DNA. These six primers were OPA-02, OPE-04, OPK-14, OPN-14, OPN-16, and OPW-19. The criteria for determining primer suitability were the number of amplified DNA fragments, their reproducibilty, and their quality, in terms of producing clear and unumbiguous DNA banding patterns. Two decamer primers were finally chosen based on these criteria: OPA-02 ('TGCCGAGCTG') and OPN-16 ('AAGCCGACCTG'). PCR products are visualized on $2 \%$ agarose in $1 \times$ TBE buffer, using Good View (Microzone, UK) as nucleic acid stain. The gel was run on electrophoresis apparatus on $110 \mathrm{~V}$ for $45 \mathrm{~min}$. Gel picture was observed under UV illuminator and documented using digital camera. The banding pattern of DNA fragment was coded numerically to produce binary data representing absence (0) or presence (1) of a band at particular molecular weight. The data was then subjected to cluster analysis using MVSP 3.1 (Kovach, 2007).

\section{Results and Discussion}

Two primers used in this study were successfully amplified DNA samples from 13 accessions of pummelo from Yogyakarta, and additional three registered pummelo cultivars ("Pamelo Magetan", "Pangkajene Merah", and "Pangkajene Putih"). A total of 222 scorable bands were produced, with 174 being polymorphic (Figure 1). The reproducibility of RAPD was assured from identical results of banding patterns from two consecutive amplification reactions.

Taxonomic affinity of pummelo accessions was examined based on result of 

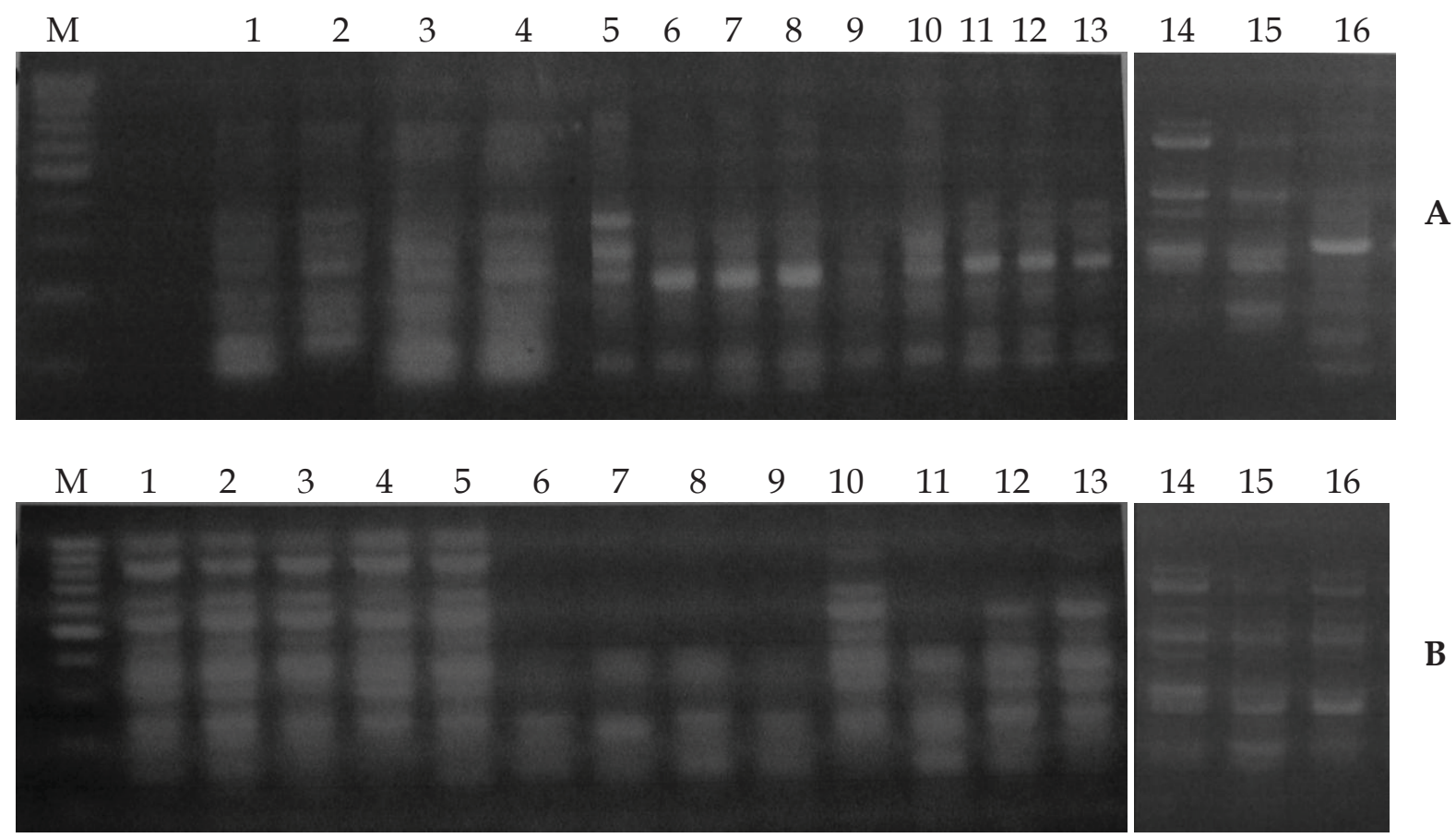

Figure 1. RAPD profile of 13 accessions pummelo from Yogyakarta and three cultivars using primer OPA-02 (A) and OPN-16 (B).

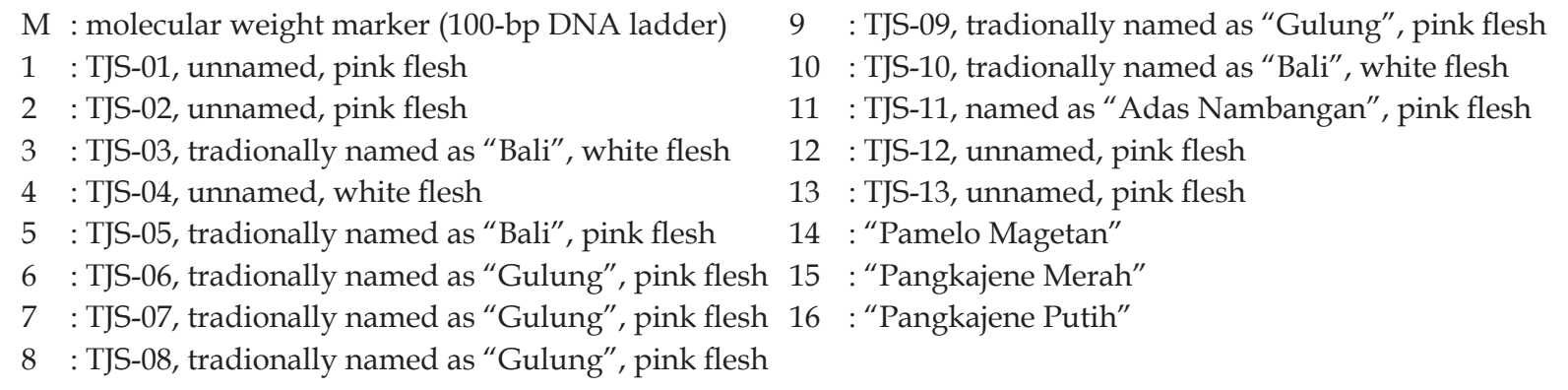

cluster analysis, represented as dendrogram (Figure 2). The dendrogram was constructed based on Simple Matching Coefficient values as a measure of similarity among accessions. The similarity values are indicating the degree of genetic similarity. The overall topology of dendrogram is thus representing the level of genetic variability of pummelo.

Results of RAPD fingerprinting showed a high degree of genetic variability among samples, indicated with $78.4 \%$ polymorphism in the amplification products. This result was of comparable extent in defining the degree of genetic variability as reported by Sheidai et al. (2010) in the analysis of genetic diversity of brown olive (Olea cuspidata). The polymorphism of RAPD fingerprinting, as represented by the presence or absence of amplification products, functions as genetic markers (Williams et al. 1990; Newbury \& Ford-Lloyd, 1993), and provide highly informative characters for the evaluation of genetic similarity (Weising et al., 1995).

The grouping pattern of accessions in the dendrogram showed the existence of two main cluster or groups. The first cluster (group I) consisted of four accessions traditionally named as "Jeruk Gulung" with pink flesh. This group of accessions is lessprefered pummelo due to its sweet-sour taste, and even with a reasonable degree of bitterness. The second cluster (group II) 


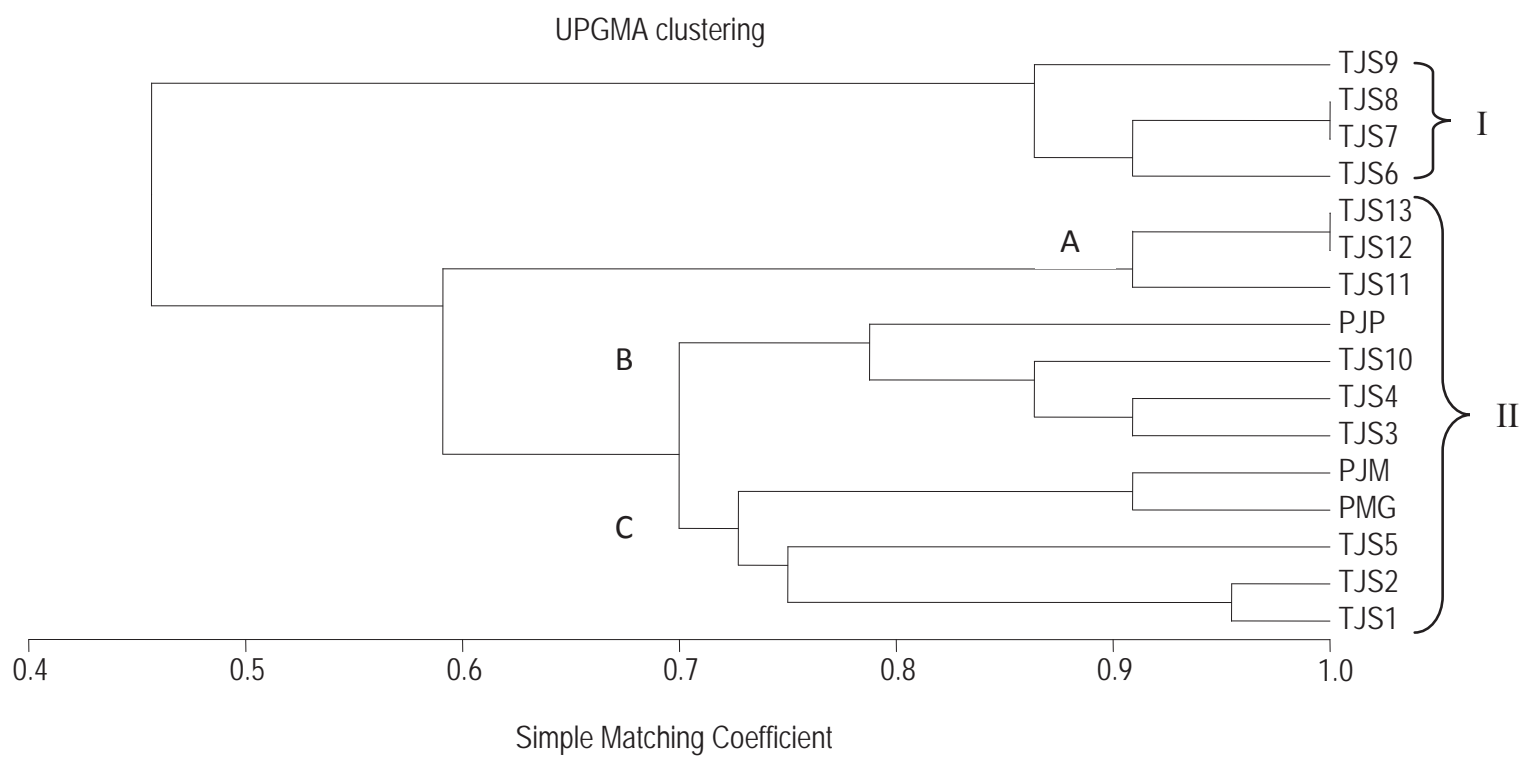

Figure 2. Dendrogram showing genetic variability and taxonomic affinity of pummelo accessions

consisted of 9 local accessions and 3 named cultivars of pummelo. This cluster was clearly divided into three sub-clusters (A, $B$. and $C$ ), with the first sub-cluster being separated at substantial degree from the other two. The three accessions within subcluster A could be regarded as a group of "Adas Nambangan", a typical pummelo with palatable taste of sweet-sour but lack of bitterness in their fruit taste. The sub-cluster B comprised of accessions with white flesh and sweet fruit taste, with "Pangkajene Putih" cultivar was among the members of the group. This sub-cluster was then could be referred to the commonly known as "Bali Putih" pummelo type. Meanwhile, the sub-cluster C with "Pamelo Magetan" and "Pangkajene Merah" cultvars were nested together with two accessions of pummelo with pink flesh and sweet fruit taste could be denoted as those commonly known as "Bali Merah".

The conformity of clustering result based on RAPD analysis to morphological and agronomical characters observed in this study was in agreement to the finding of Corazza-Nunes et al. (2002) in the assessment of genetic variability in Citrus paradisi and Citrus maxima. Results of this study also indicated the existence of infraspecific variability within pummelo, and showed the grouping of accessions into recognizable types. This finding was in line with the study of characterization of Citrus cultivars and clones using RAPD as reported by Hvarleva et al. (2008).

The application of RAPD fingerprinting in infraspecific taxa has been concerned with two major objectives, either for the estimation of genetic variability or cultivar identification. The combination of these two objectives has been reported in various fruit crops, such as in Cucumis satious and Benincasa hispida by Saengprajak \& Saensouk (2012) and sugar apple (Annona squamosa) by Guimarães et al. (2013). The ability of RAPD in providing evidence on the occurrence of infraspecific genetic variability within cultivated plants was reported previously by Mahasi et al. (2009) in their study on genetic polymorphisms in Carthamus tinctorius.

\section{Conclusion}

Pummelo (Citrus maxima) accessions from Yogyakarta have a high degree of genetic variability as indicated by the high percentage of RAPD fingerprinting polymorphisms. The application of RAPD 
fingerprinting technique for the assessment of genetic variability in C.maxima was proven to be effective in revealing infraspecific variability and taxonomic affinity. The grouping of pummelo accessions based on RAPD analysis was in agreement to the agromorphological characters.

\section{Acknowledgement}

The authors acknowledge financial support from I-MHERE Project 20102011, Faculty of Biology UGM for the accomplishment of this research.

\section{References}

Agisismanto, D. dan Supriyanto, A. 2007. Keragaman genetik pamelo di Indonesia berdasarkan primer random amplified polymorphic DNA. Jurnal Hortikultura 17 (1): 1-6.

Arora, R.K. 2000. In Situ Conservation of Biological Diversities in Citrus. GCGN Meeting, 7-8 December 2000.

Baig, M.N.R., Grewal, S. and Dhillon, S. 2009. Molecular characterization and genetic diversity analysis of citrus cultivars by RAPD markers. Turk J Agric For 33: 375-384.

Corazza-Nunes, M.J., Machado, M.A., Nunes, W.M.C., Cristofani, M., and Targon, M.L.P.N.. 2002. Assessment of genetic variability in grapefruits (Citrus paradisi Macf.) and pummelos (C. maxima (Burm.) Merr.) using RAPD and SSR markers. Euphytica 126: 169-176.

El-Mouei, R., Choumane, W., and Dway, F. 2011. Molecular characterization and genetic diversity in genus Citrus in Syria. Int. J. Agric.Biol. 13: 351-356.

GEF. 2006. Citrus: Conservation and Sustainable Use of Cultivated and Wild Tropical Fruit Diversity: Promoting Sustainable Livelihoods, Food Security and Ecosystem Services.

Guimarães, J.FR., Silvia, N., Costa, M.R., Moreira, G.B.R., Pereira, M.C.T., Vendrame, W. 2013. Genetic diversity in sugar apple (Annona squamosa L.) by using RAPD markers. Revista Ceres 60 (3): 428-431.

Hvarleva, T, Kapari-Isaia, T., Papayiannis, L., Atanassov, A., Hadjinicoli, A., Kyriakou, A. 2008. Characterization of Citrus Cultivars and Clones in Cyprus through Microsatellite and RAPD Analysis. Biotechnol. \& Biotechnol. Eq. 22 (3): - 794.

Karsinah, Sudarsono, Setyobudi, L. dan Aswidinoor, H. 2002. Keragaman genetik plasma nutfah jeruk berdasarkan analisis penanda RAPD. Jurnal Bioteknologi Pertanian 7 (1): 8-16.

Kovach, W.L. 2007. MVSP - a multivariate statistical package, 3.1. Pentraeth, Wales: Kovach Computing Services.

Mahasi, M.J., Wachira, F.N., Pathak, R.S., and Riunyu, T.C. 2009. Genetic polymorphism in exotic safflower (Carthamus tinctorius L.) using RAPD markers. J. Plant Breed. Crop Sci. 1 (1): 8-12.

Newbury, H.J. \& Ford-Lloyd, B.V. 1993. The use of RAPD for assessing variation in plants. Plant Growth Regul. 12: 43-51.

Niyomdham, C. 1992. Citrus maxima (Burm.) Merr. In: Plant Resources of South-East Asia. No.2: Edible Fruits and Nuts. (Coronel, R.E. \& Verheij, E.W.M. (Eds.). Prosea Foundation, Bogor, Indonesia. pp. 128-131.

Prasad, M.P. 2014. Molecular Characterization of Medicinal Plant Species of Acathaceae Family Using RAPD Molecular Markers. Int. J. Sci. Res. 3 (9): 505-507.

Purwanto, E., Sukaya, dan Merdekawati, P. 2005. Studi Keragaman Plasma Nutfah Jeruk Besar Di Magetan Jawa Timur Berdasar Penanda Isozim.

http://pertanian.uns.ac.id/ agronomi/ agrosains/kerg_plasmnut_jerk_ edipurwanto.pdf

Rakhman, M.A., Respatijarti, dan Sugiharto, A.N. 2005. Keragaman Tanaman Pamelo (Citrus grandis (L.) Osbeck) 
di Kabupaten Magetan Berdasarkan Karakter Morfologi Dan Analisis Isozim. http://mukhtaromali. blogspot.com/2008/02/variabilitiesof-pummelo-c-grandis-1.html

Saengprajak, J. and Saensouk, P. 2012. Genetic diversity and species identification of cultivar species in subtribe Cucumerinae (Cucurbitaceae) using RAPD and SCAR markers. American Journal of Plant Sciences 3: 1092-1097.

Sheidai, M., Noormohammadib, Z., Dehghania, A., Parvinia, F., HoshiarParsiana, $\mathrm{H}$ and Hosseini-Mazinani, M. 2010. Intra-specific morphological and molecular diversity in brown olive (Olea cuspidata) of Iran. ScienceAsia 36: 187-193. doi: 10.2306/scienceasia15131874.2010.36.187

Trinh, LN, Watson J.W., Hue, N.N, De Minh, N.V, Chu, P, Sthapit, B.R. and Eyzaguirre, P.B. 2003. Agrobiodiversity conservation and development in Vietnamese home gardens. Agr. Ecoyst. Environ. 2033:1-28.

Weising, K., Nybom, H., Wolff, K., and Meyer, W. 1995. DNA Fingerprinting in Plants and Fungi. CRC Press, Florida.

Williams, J.G.K., Kubelik, A.R., Livak, K.J., Rafalski, J.A., and Tingey, S.V. 1990. DNA polymorphisms amplified by arbitrary primers are useful as genetic markers. Nucleic Acids Res. 18 (22): 6531-6535. 